\title{
A Suggested Test for Application of the Main Purpose Rule Under the Statute of Frauds
}

\author{
Lazerence P. Simpson*
}

A PROMISE OF suretyship or guaranty may be made either at the time the principal debt is contracted and upon the same consideration of detriment to the creditor by the extension of credit, or it may be made subsequent to that time, to answer for the debt of another antecedently contracted. In the latter case, the new promise must, of course, be supported by a separate consideration. A new promise which discharges another's obligation by novation, or one in which no obligation of another exists or is contemplated, is necessarily original since there can be no debt of another. Where, however, the debt of another continues to exist, a new promise by a third party to pay it has, from the very beginning, been considered outside the Statute where made under such circumstances as to render the new promisor himself a debtor. A promise to pay one's own debt is not within the Statute of Frauds even though performance of the promise will incidentally result in discharge of the debt of another. The consideration for the new promise has always been the chief circumstance with which the courts have concerned themselves. An early English case ${ }^{2}$ pointed out the "distinction between a promise to pay the original debt, and on the foot of the original contract, and where it is on a new consideration." In 1811 it was laid down by Chancellor Kent that "when the promise to pay the debt of another arises out of some new and original consideration of benefit or harm moving between the newly contracting parties" it is not within the Statute. ${ }^{3}$ That this statement was too broad in that it included mere harm to

* Professor of Law, New York University.

1 "When the primary debt continues to exist, the promise of another to pay the debt may be original, or it may not be; but it is regarded as original only when the party sought to be charged clearly becomcs, within the intention of the parties, a principal debtor primarily liable." Richardson Press v. Albright (1018) 224 N.Y. 497, 502,121 N. E. 362,364 .

2 Tomlinson v. Gill (1756) 27 Eng. Rep. 221.

3 Leonard v. Vredenburgh (N. Y. 1811 i 8 Johns $29,39$. 
the creditor promisee was early recognized, ${ }^{4}$ and the test was limited to a new consideration of benefit to the new promisor. ${ }^{5}$ As pointed out, good consideration for the new promise must exist before the question of the Statute of Frauds can arise. If any consideration, either of detriment to the promisee or benefit to the promisor, is sufficient to take a new promise out of the Statute, nothing would remain for it to operate upon except collateral promises made concurrently with the inception of the debtor's obligation and upon the same consideration. Now that the point of agreement has been reached that the separate consideration for the new promise must be one of direct benefit to the promisor in order to take the oral promise out of the Statute, and that mere detriment to the promisee creditor is insufficient, the subsequent divergence in the cases has centered about such questions as the kind of benefit, how much benefit, how direct must it be, and even what form the new promise must take.

The test which has gained widest acceptance in the American cases is the purpose of the promisor. Chief Justice Shaw in the leading case of Nelson v. Boynton ${ }^{6}$ stated the rule derived from the cases to be that where the leading object of the promisor is to become a guarantor or surety for a debt on which a third party is liable, the promise, whether made before or after or at the time of the promise of the principal, is within the Statute; but where the main purpose of the promisor is to subserve some pecuniary interest of his own, notwithstanding the effect is to pay or discharge the debt of another, his promise is not within the Statute. ${ }^{7}$ The assumption is that it is possible for a court to infer from the circumstances of any given case whether the "leading object" of the promisor was to become a surety for another or whether it was to secure a pecuniary advantage to himself and so

4 This dictum is now generally discredited. BRowne, Statute of Frauds 812 (5th ed. 1895); 2 Writston, Contracts \$ 472 (rev. ed. 1936); Amold, The Brain Purpose Rule and the Statute of Frauds (1924) 10 Cors. L. Q. 28. Burdick, Suretyship and the Statute of Frauds (1920) 20 CoL. L. Rev. 153; Carey, Guaranties and the Statute of Frauds in Wisconsin (1923) 2 WIs. L. REv. 193.

5 Mallory v. Gillett (1860) 21 N. Y. 412.

6 (Mass. 1841) 3 Metc. 396, 402.

T The language is that of the Pennsylvania court elaborating Justice Shaw's rule in Nugent v. Wolfe (1886) $111 \mathrm{~Pa} .471,480,4$ Atl. 15, 17. The same principle is stated in Barbour v. Thomas (E. D. Mich. 1933) 7 F. Supp. 271; Clifford v. Luhring (1873) 69 III. 401 ; New Amsterdam Cas. Co. v. Madison County Tr. Co. (1924) 81 Ind. App. 157, 142 N. E. 727 ; Frohardt Bros. v. Duff (1912) 156 Iowa 144, 135 N. W. 609 ; Oldenburg \& Kelley v. Dorsey (1905) 102 Md. 172, 62 Atl. 576; Davis v. Faulkner (1923) 186 N. C. 439,119 S. E. 819 ; Bellows v. Sowles (1884) 57 Vt. 164; Guth v. First Nat. Bank (1926) 137 Wash. 280, 242 Pac. 42. 
in effect to answer for his own debt. But in a particular case both purposes may exist and neither be stronger than the other. The controlling circumstancee from which the inference must be made is the consideration received by the oral promisor. In many situations in which the consideration is forbearance by the creditor, the benefit to the new promisor from such forbearance is so equivocal as to afford no basis for an inference as to which was his primary purpose. A test as vague as the main purpose rule provides no forward step in certainty or predictability. The consideration must be pecuniarily beneficial to the oral promisor. but questions still remain. How direct must be the benefit? How substantial must it be before a court can say that the oral promise is to answer for the promisor's own debt and that therefore to permit him to escape liability by pleading the Statute would be using the Statute to perpetrate a fraud? Since the cases for the most part fall into well recognized categories, it will be of value to consider the results reached in each category in an attempt to reach an underlying principle which will explain their diversity.

First, the "property cases." Surrender by the creditor to the new promisor of property or a lien upon property, held by the creditor as security for his claim, takes the oral promise out of the Statute provided the property either belongs to the new promisor or is property in which he has a substantial interest which is thus promoted by the surrender. ${ }^{10}$ For example, if $P$ has mortgaged his house to secure a

8 In Cowenhoven v. Howell (1873) 36 N. J. L. 323, 325, the court said: "In case of a promise to become liable for an existing debt, there must. in order to sustain such promise, ... be a substantial consideration moring to such promisor. . . Agreements which will have the effect to discharge the debt of another must be founded in a motive of interest, selfish in the promisor. The distinction is between a promise. the object of which is to promote the interest of another, and one in which the object is to promote the interest of the party making the promise. The former is within the operation of the Statute. The latter is unaffected by it."

${ }^{9}$ A typical case is Maine Candy \& Products Co. v. Turgeon (1925) $124 \mathrm{Me}$. 411, 130 Atl. 242 , in which the consideration for defendant's promise to pay the debt of his son-in-law was plaintiff creditor's forbearance to sue the son-in-law or to set aside a sale of a busmess and attach assets of the business which defendant had purchased from the son-in-law. The promise was held outside the Statute. See also Davis v. Patrick (1891) 141 U. S. 479; Frobardt Bros. v. Duff (1912) 156 Iowa 144, 135 N. W. 609; Cross v. Richardson (1858) 30 Vt. 641.

10 Dueholm v. Stern (1899) 86 Ill. App. 649; Simpson v. Carr \& Parrigin (1903) 25 Ky. L. Rep. 849, 76 S. W. 346; Manning v. Anthony (1911) 208 Mass. 399, 94 N. E. 466; Prime v. Koehler (1879) 7t N. Y. 91 ; Rogers v. Gennett Lumber Co. (1910) 154 N. C. 108,69 S. E. 788; Bova v. Scorpio (1920) 43 R. I. 98, 110 Atl. 417 ; Dybdahl v. Continental Lumber Co. (1925) 133 Wash. 81, 233 Pac. 10; Day v. Morgan (1924) 184 Wis. 595, 200 N. W. 382; Williams v. Leper (1766) 3 Burr. 1886, 97 Eng Rep. 1152 Cf. Cincinnati Traction Co. v. Cole (C. C. A. 6th 1919) 258 Fed. 169; Frohardt Bros. v. 
loan from $C$, and $S$ has bought the house from $P$ subject to the mortgage, but without assuming it, an oral promise by $S$ to $C$ to pay the mortgage debt in consideration of $C$ 's surrender of the mortgage lien is outside the Statute. ${ }^{11}$ Or a promise by a junior mortgagee to pay the debt secured by a senior mortgage in consideration of subordination of the senior lien is valid though oral. ${ }^{12}$ Such cases are clear by any test. The leading object of the promisor is to secure to himself a pecuniary advantage which he did not previously enjoy; the consideration is one of benefit to the promisor, direct to him, and substantial. It is otherwise, however, if the lien surrendered is upon property in which $S$ has no pecuniary interest that will be directly promoted by discharge of the lien, as where $S$ orally promises to pay a lien on property on which he holds a prior mortgage in consideration of $C$ 's surrender of his lien. ${ }^{13}$ Such a promise is not enforceable because the prom-

Duff (1912) 156 Iowa 144, 135 N. W. 609; Maine Candy \& Products Co. v. Turgeon (1925) 124 Me. 411, 130 Atl. 242; Colbath v. Everett D. Clark Seed Co. (1914) 112 Me. 277, 91 Atl. 1007; McKay v. Northern Bank \& Trust Co. (1912) 69 Wash. 186, 124 Pac. 372. (1917) 2 CORN. L. Q. 209; (1921) 34 HARv. L. REv. 440; (1915) 63 U. of PA. L. Rev. 230; (1914) 62 U. OF PA. L. REv. 314 ; (1924) 3 WIS. L. REv. 178.

11 Kale v. Bank of America Agricultural Credit Corp. (1934) 2 Cal. App. (2d) 113, 37 P. (2d) 494; Parker v. Dillingham (1891) 129 Ind. 542, 29 N. E .23; Hodgins v. Heaney (1870) 15 Minn. 185.

12 Westmoreland v. Porter (1883) 75 Ala. 452; Hodgins v. Heaney, supra note 11. 13 Griffin v. Hoag (1898) 105 Iowa 499, 75 N. W. 372; Mallory v. Gillett (1860) 21 N. Y. 412. In Harburg India Rubber Comb Co. v. Martin (1902) 1 K. B. 778, the court said: "Whether you look at the 'property cases' or at the 'del credere cases', it seems to me that in each of them the conclusion arrived at really was that the contraet in question did not fall within the section because of the object of the contract. In each of those cases there was in truth a main contract-a larger contract-and the obligation to pay the debt of another was merely an incident of the larger contract. As I understand those cases, it is not a question of motive-it is a question of object. You inust find what it was that the parties were in fact dealing about. What was the subject-matter of the contract? If the subject-matter of the contract was the purchase of property-the relief of property from a liability, the getting rid of incumbranees, the securing greater diligence in the performance of the duty of a factor, or the introduction of business into a stockbroker's office--in all those cases there was a larger matter which was the object of the contract. That being the object of the contract, the mere fact that as an incident to it-not as the immediate object, but indirectly-the debt of another to a third person will be paid, does not bring the case within the section. Thls definition or rule for ascertaining the kind of cases outside the section covers both 'property cases', and 'del credere cases'. . . . It was suggested that the true definition of cases which do not come within \$ 4 should be, not those in which the obligation to pay the deht of another is an incident of a larger contract, but those in which the main object is to secure the promisor's own personal interest. But, I think, if such a definition were adopted, there would be notbing left to come within $\$ 4$, because in every case there must be a consideration for which the promisor bargains to come to him from the promisee. That is as true of mere forbearance as of anything else." 
isor acquires no interest. by the promisee's release of the lien, which he did not before possess. His "main purpose." then. can only be to answer for another's debt.

The second class of cases, the document cases, are uniformly held outside the Statute. An oral guaranty of another's obligation, if made as inducement for and in connection with a sale of the obligation, although in form a promise to answer for the debt of another, has always been held an original promise. If $S$, payee of a note on which $P$ is maker, in connection with his sale of the note to $C$, guarantees that $P$ will pay, $S$ 's promise is enforceable though oral. In this case, not only is $S$ guaranteeing the value of the thing he is selling, but also a substantial part of that which he is selling is his guaranty. As such, it is his own debt. "No good reason can be urged why the debtor should escape his liability merely because his promise was made in such form that when carried out it discharges the debt of another." ${ }^{14}$ The courts hold such promises not within the Statute. ${ }^{15}$ In Hargreaves v. Parsons ${ }^{16}$ defendant induced the plaintiff to purchase his rights in corporate stock to be issued by orally guaranteeing that the corporation would perform. The defendant's promise was held to be not within the Statute. ${ }^{1 \tau}$ In a typical case, the Court of Appeals of New York said: "It is claimed that the guaranty is void by the Statute of Frauds. In mere form it is certainly a collateral undertaking, because it is a promise that another person should perform his obligation. But, looking at the substance of the transaction, we see that the defendant paid, in this manner, a part of the price of a horse sold to himself. In a sense merely formal, he agreed to pay his vendor so much of the price of the chattel, unless a third person should make the payment for him."18 Included in this class also is the case where $S$ induces his creditor to accept $P$ 's note payable to $S$, in discharge of his own debt, by

14 Stearns, Suretyship § 42 (rev. ed. 1922).

15 State Bank of Pike v. People's Nat. Bank of Franklinville (Sup. Ct. 1909) 118 N. Y. Supp. 641 ; Brookline Nat. Bank v. Moers (1st Dept. 1897) 19 App. Div. 155, 45 N. Y. Supp. 997; Cardell v. MoNeil (1860) 21 N. X. 336; Brown v. Curtiss (1849) 2 N. Y. 225; Wilson, Van Saun \& Co. v. Hentges (1882) 29 Minn. 102, 12 N. W. 151 ; Kiernan v. Kratz (1902) 42 Ore. 4it, 69 Pac. 1027; Crawford v. Pyle (1899) $190 \mathrm{~Pa}$. 263, 42 Atl. 687; Hargreaves v. Parsons (1844) 13 M. \& W. 561, 153 Eng. Rep. 235; Browate, Statute of Frauds $\$ 165$ (5th ed. 1895); 2 Williston, Contracts $\$ 484$. But see Dows v. Swett (1883) 134 Mass. 140; Francois v. Cady Land Co. (1912) 149 Wis. 115,135 N. W. 484.

16 (1844) 13 M. \& W. 561, 570, 153 Eng. Rep. 235, 238.

$17 \mathrm{~A}$ sale of stock with an oral guaranty of future dividends to be declared would not be within the Statute. since there is no "debt or obligation" of another.

18 Cardell v. McNiel (1860) 21 N. Y. 336, 340. 
promising orally that he will pay if $P$ does not. Here $S$ is promising to pay what in substance is his own debt. In an early case, ${ }^{10}$ where the defendant orally guaranteed that the maker of a bearer note would pay it, in order to induce plaintiff to accept its transfer in payment of defendant's note, it was held that the oral guaranty was not within the Statue. Bronson, J., said: "Although in form this is a promise to answer for the debt or default of another, in substance it is an agreement to pay the guarantor's debt in a particular way. He does not undertake as a mere surety for the maker, but on his own account, and for a consideration which has its root in a transaction entirely distinct from the liability of the maker. The defendant was a debtor of the plaintiff and gave the note, with the guaranty, to satisfy that debt." The document cases seem to have been suggested as a separate classification by the case of Castling v. Aubert. ${ }^{20}$ There the plaintiff, a broker, had a lien on insurance policies belonging to a customer to secure repayment of premiums paid by the broker with his acceptances. The defendant, to induce surrender of the lien on the policies so that he could collect from the insurers, orally promised plaintiff that he would pay plaintiff's acceptances at maturity. This oral promise was held not to be within the Statute. Lord Ellenborough said that the transaction amounted to a purchase by the defendant of the plaintiff's interest in the policies. It is apparent that the situation is indistinguishable from the cases in which the consideraton for the new promises is surrender by the creditor of a lien upon property owned by the promisor or in which he expects to have a present interest.

In a third class of cases, the stockholder cases, the principal debtor is the corporation, and the consideration for the new promises inures to the benefit of the corporation directly, the promisor stockholder being benefitted only through his stock ownership. Even though a promisor has a substantial interest to subserve in making his promise, unless the benefit will result to him directly, the promise is deemed collateral. If the consideration was in fact to be received by and become advantageous to the debtor, then even though the promisor will be benefitted indirectly, and even though acquisition of such benefit was the main purpose inducing the promise, the Statute is a bar to an action. Only where the benefit is substantial, "direct, immediate and 
personal to the promisor"'21 can it be said that he is orally answering for his own debt. Thus a promise by a stockholder of a corporation to pay for goods or services rendered the corporation for which the corporation is also liable is usually held a collateral promise. For example, $S$, stockholder and director of $P$ corporation and owner of some of its bonds, to induce $C$ to make advances to the corporation or refrain from levying on its property, orally promises $C$ that he will be responsible for the debt to be incurred or already existing. That his dominant purpose is to promote his financial interests as creditor and stockholder is obvious; that $C$ 's act or forbearance promotes $S$ 's financial interests is also clear. There was no thought of accommodating another. But for the purpose of pecuniary gain to himself he would not have promised. Yet such promises are very widely held to be within the Statute. ${ }^{22}$ If the only benefit to the promisor is through his stock ownership, shared with the other stockholders as it is, this is regarded as too indirect and remote to render the promisor a debtor so as to take his promise out of the Statute. Where the promisor owns all or substantially all of the corporate stock. it has been held that sufficient consideration inures to him personally to make the promise original, ${ }^{23}$ although the cases on this point are not at all uniform. ${ }^{24}$

Fourth, a very large number of cases have arisen in which an owner, faced with stoppage of construction of his building because of refusal of a subcontractor to furnish further labor and materials on the credit of the principal contractor alone, orally promises the subcontractor to pay. The following possibilities exist: (1) the promise may be absolute in terms. as "I will pay": (2) the promise nay be conditioned upon the principal contractor's default, as "I guarantee payment" or "I will see you paid": (3) the promise may be to pay out of the money due the principal contractor; (4) the promise may be to pay for labor and materials already due from the general contractor and also for labor and materials thereafter to be furnished; (5) the promise may be to pay only for what is furnished after the making of the promise; (6) the promise may occur after the contractor has abandoned the contract; or (7) it may occur before such

21 Hurst Hardware Co. v. Goodman (1010) 68 W. Va. 462, 69 S. E. 898.

22 See Note, 8 A. L. R. 1198 (1920).

23 Davis v. Patrick (1891) 141 U.S. 479; Donovan v. Purtell (1905) 216 III. 620. 75 N. E. 334.

24 Bulkey v. Shaw (1942) 289 N. Y. 133, 44 ‥E. (2d) 398; Richardson Press : Albright (1918) 224 N.Y. 497, 121 N. E. 362 : Goldie-Klenert Distributing Co. v. Bothweil (1912) 67 Wash. 264. 121 Pac. 60. 
abandonment. In all of the above situations it is probably equally true that the main purpose of the owner promisor is to subserve a pecuniary purpose of his own, i.e., to get his building finished. It is also true that the consideration for the new promise is a substantial benefit inuring directly to the promisor, since all labor and material furnished goes immediately into the building belonging to the promisor. Yet in the cases the effect of the Statute of Frauds on the oral promise has been made to turn upon which of the above conditions exists. ${ }^{25}$ Where the promise of the owner is absolute in terms, to pay for labor and materials furnished after the making of the promise, it has universally been held original and outside the Statute..$^{20}$ On the other hand, where the promise is conditioned upon the principal contractor's default, and includes what the general contractor is already liable for to the promisee, it is usually held collateral..$^{27}$ Promises by the owner to pay the subcontractor only out of money due the general contractor are clearly original, ${ }^{28}$ as are promises made to the subcontractor after the principal contractor has abandoned the contract, since here the owner is the sole debtor. ${ }^{29}$ Where the oral promise is absolute in form and includes labor and materials for which the general contractor is already indebted to the promisee, as well as those to be furnished thereafter, the cases frequently construe the promise as severable and permit the Statute as a defense to the former

25 See Note, 99 A. L. R. 79 (1935).

${ }^{26}$ Shisler v. Moore (C. C. A. 3rd 1927) 19 F. (2d) 991 ; Sext v. Geise (1888) 80 Ga. 698, 6 S. E. 174; Berkowsky v. Viall (1896) 66 Ill. App. 349; Owen v. Stevens (1875) $78 \mathrm{Ml} .462$; Rand v. Mather (Mass. 1853) 11 Cush. 1; Grant v. Wolf (1885) 34 Minn. 32, 24 N.W. 289; Paul v. Haber (1915) 88 N. J. L. 379, 96 Atl. 41 ; Block v. Galitzka (2d Dept. 1906) 114 App. Div. 799, 100 N. Y. Supp. 173; Kampman v. Pittsburgh Contracting \& Engineering Co. (1934) 316 Pa. 502, 175 Atl. 396.

2i Gill v. Herrick (1873) 111 Mass. 501; Whitschard v. A. Brody \& Sons (1931) 257 N. Y. 97,177 N. E. 385 ; Leichtman v. Stein (1914) 3 Ohio App. 15; Mackey v. Smith (1872) 21 Ore. 598, 28 Pac. 974; Housley v. Strawn Mdse. Co. (Tex. 1927) 291 S. W. 864 ; Engleby v. Harvey (1896) 93 Va. 440, 25 S. E. 225.

28 Bates v. Paint \& Glass Co. (1905) 143 Ala. 198, 38 So. 845; Robinson \& Son Contracting Co. v. Twin City Bank (1912) 103 Ark. 219, 146 S.W. 523; Stoelker v. Chicago Bldg. Supply Co. (1887) 22 Ill. App. 625; Raabe v. Squier (1895) 148 N.Y. 81,42 N. E. 516.

29 "The new promise of the owner of the building, in such a case, is not, so far as future work is concerned, to pay the debt of the general contractor. The Jatter will owe no debt for this performance, for it was not rendered in performance of the contract with him, and the promise of the owner is not to pay the debt of the general contractor, though the amount of his own debt may be fixed by the obligation which the general contractor would have incurred had his contract not been abandoned." WnLIstow, CONTRACTS $\$ 481$. 
items but refuse it as a defense to the latter."in These principles apply also where the new promise is made by someone, other than the owner. interested in completion of the building, as where the general contractor promises a materialman supplying material to a subcontractor."i1 or a mortgagee on a building loan promises a subcontractor to pay for labor supplied::2 Release of a mechanic's lien perfected against the building is, of course, always such consideration of direct benefit tn the owner as will take his oral promise to pay the subcontractor ou: of the Statute. ${ }^{33}$

Both the Restatement of Contracts ${ }^{34}$ and of Security ${ }^{35}$ adopt the main purpose rule and carry it to its logical conclusion in the building contract situation, so as to include as original even promises by an owner in form conditioned on the principal contractor's default to pay for inaterials already due, as well as those yet to be furnished."is As indicated above, the results in the cases do not bear out the Restatement rule.

\section{Suggested Test of Equivalency of Benefit to Obligation Undertaken} Under all tests of the enforceability of oral promises, the inquiry has centered on the consideration for which the promise was given: ${ }^{37}$

${ }^{30} \mathrm{~A}$ promise in terms to pay for materials already furnished and also for materials thereafter to be furnished is said to be severable and may be enforced as to the subsequently furnished materials though the Statute is a good defense as to the materials previously furnished. Peterson v. Paxton-Pavey Lumber Co. of Florida (1931) $102 \mathrm{Fla}$. 89, 135 So. 501 ; Board of Commissioners v. Cincinnati Steam-Heating Co. (1891) 128 Ind. 240,27 N. E. 612 . See also Belknap v. Bender (1878) 75 N. Y. 446.

31 Davis Const. Co. v. Petty (1929) 91 Ind. App. 147, 168 N. E. 769. In McMillian v. Dickover (1926) 119 Ore. 116, 248 Pac. 154, the oral promise of the contractor to pay for materials to be furnished the subcontractor was held collateral because it did not appear that the materials were sold on the contractor's sole credit.

32 Ribock v. Canner (1914) 218 Mass. 5, 105 N.E. 462.

33 Fuller v. Towne (1920) 18+ Cal. 89, 193 Pac. 88; McDonald v. General Const. Co. (1911) 152 Iowa 273, 132 N. W. 369 ; Cooper v. Kelley \& Kelley (Sup. Ct. 1917) 164 N. Y. Supp. 828.

34 Restatement, Contracts § 184 (1932).

35 RESTATEMENT, SECURITY § 92 (1941).

${ }^{36}$ Id., Illustration 1. Cited with approval in Kampman v. Pittsburgh Contracting \& Engineering Co. (1934) $316 \mathrm{~Pa} .502,175$ Atl. 396.

37 The test of the Statute proposed by Professor Arant was also based on the character of the consideration received by the new promisor. If it was directly beneficial, then no matter how small in relation to the obligation assumed, the new promise should be held outside the Statute. "Where $C$ alleges that $S$ orally promised to pay him what $P$ owed, if $P$ did not, in consideration of the delivery by $C$ to $S$ of a book or other article of value, the promise of $S$, according to the theory here advanced, should be held to be without the Statute of Frauds. It cannot be denied, however, that some decisions are incompatible with this theory." ARANT, SURETYSEIP 114 (1931). His approach was 
Was it pecuniarily beneficial to the promisor, as distinguished from mere detriment to the promisee creditor? Did the benefit accrue directly and immediately to the new promisor? Finally was it sufficiently substantial so that it can be said that the main purpose of the promisor was to answer for his own debt; or, on the other hand, was it measured in amount merely by the risk assumed by the new promisor in having to pay the debt of another so that his purpose was merely to become a surety? The test here suggested is: If the beneficial consideration received, whether moving from the debtor ${ }^{38}$ or the creditor, is the equivalent, or is bargained for as the equivalent, of the obligation undertaken, then, even though the debt of another continues to exist the oral promise is outside the Statute as a promise to answer for a debt which is the promisor's own. On the other hand, where the consideration received is equivalent merely to the risk undertaken by the promisor of having to pay the debt of another, the oral promise is within the Statute. Professor Williston first pointed this out as an important distinction to be made, but discarded it as a test of the Statute of Frauds because he concluded that it was a situation which simply would not happen. He said: "The new promisor may propose to purchase property or rights and in return for them pay the debt as the price. Such a bargain presupposes that the consideration re-

that oral promises which were outside the dangers aimed at by the Statute should be enforced. If the fact that the promise was actually made is capable of objective proof, not resting alone upon the testimony of the creditor, there can be no objection to enforcing it. Where the consideration for the new promise of $S$ is mere detriment to the creditor, as when he releases a lien upon P's land, "there is no benefit to $S$ that is particularly suggestive of an inducing promise by him to $\mathrm{C}$. Parol evidence here is the sole basis of the inference that S promised." Id. at 117. But where $C$ releases a lien upon P's land which secures a debt upon which $P$ remains liable, "the natural inference is that the person most immediately and directly benefited by the act or forbearance is the person who induced it, because promises are generally made to promote the promisor's interest. Hence, ... . parol evidence may be trusted to corroborate the inference naturally to be drawn from defendant's receipt of a substantial benefit at the plaintifi's hands." Id. at 117. In short, any beneficial consideration moving from the creditor to the new promisor makes it probable that the promise was made; in such case the creditor's oral testimony as to the fact of the promise is merely corrobatory; therefore the situation is not one at which the Statute was aimed, and such promises should be held outside the Statute.

38 Assumption agreements by the grantee in a conveyance of real estate or personal property, to pay grantor's indebtedness secured by a mortgage upon the property conveyed as part of the purchase price, are examples of beneficial consideration equal to the obligation assumed by a new oral promise to the creditor to pay the mortgage debt. That the ronsideration moves from the debtor rather than from the promisee creditor is immaterial. That the oral promisor is answering for his own debt, created by the previous undertaking with the grantor, upon which the creditor had already a remedy as third party creditor beneficiary without the oral promise, is clear. 
ceived is the equivalent, or so regarded, of the debt. It is obvious that the creditor will never furnish consideration to this amount for a new promise. He already has the original promise, and if he is to furnish consideration equal in value to the amount of the debt, he will prefer to get not simply a new promise but the promise of a new debt, equal in amount to the old indebtedness. The debtor, however, or one acting in his interest, may be entirely willing to give the promisor consideration equal in value to the debt in return for the promisor's agreement to discharge it; and where such a bargain is made, the latter's promise to pay the debt may be, and as matter of fact is, sometimes made to the debtor, sometimes to the creditor, and sometimes to both. Promises of this type are not within the Statute." 39

It is true only in a limited sense that a creditor, having already the obligation of the original debtor, will never furnish consideration equivalent in value to the debt for a new promise to pay it. He will not furnish new tangible consideration to such an amount without an independent debt obligation to pay for it; but he may furmish an intangible consideration to the anrount of such equivalency, as by surrender of a lien which he holds upon the new promisor's property. In other words, a creditor may, and very often does, accept in substitution for the lien which he holds as security for the original debt, the security of the personal obligation of a new promisor. This is the situation in the property cases under the main purpose rule. For example, where $S$, having bought from $P$ a stock of goods valued at $\$ 16,000$, upon which $C$ has a mortgage lien to secure a $\$ 6,000 \mathrm{debt}$ due from $P$, orally promises $C$ to pay the debt in consideration of $C$ 's surrender of the lien on the goods, the value of $S$ 's ownership will increase from $\$ 10,000$ to $\$ 16,000$. In other words, as beneficial consideration for his oral promise to pay $P$ 's debt of $\$ 6,000, S$ will receive $\$ 6,000$ of value from $C$. There can be no doubt that any court would hold $S$ 's promise outside the Statute. His main purpose is not to become surety but to subserve a pecuniary interest of his own to such an extent that it can be said that he is primarily answering for his own debt.

Where a new promisor promises to pay an obligation for which another person remains liable. the necessary consideration may consist solely in detriment to the promisee or it may constitute also a benefit to the promisor. Where the consideration is pecuniary benefit to the new promisor, two possibilities exist as to the purpose of the

Wriston, Contracts $\$ 473$. 
promisor im bargaining for such benefit: (1) he may have bargained for it as the price of the risk undertaken of having to pay another's debt; or (2) he may have bargained to secure the benefit as his ultimate aim, the element of answermg for another's debt being merely incidental thereto. In the former case the oral promise is within the Statute; in the latter case it is not. Thus not all considerations of pecuniary benefit to the new promisor take the oral promise out of the Statute of Frauds; under the main purpose rule, some do and some do not. If the fundamental requisite underlying the rule is that the Statute should never bar enforcement of an oral promise where the promisor is answering for a debt which is substantially his own, then the question of how much pecuniary benefit was bargained for and received by the new promisor in relation to the obligation assumed becomes the determinative factor. If the value of the benefit is equivalent to the obligation assumed, the main purpose of the promisor is to answer for his own debt; but if it is merely the equivalent of the risk of having to pay the debt of another, his nain purpose is to become a surety, and the oral promise is within the Statute.

It is important to note that this suggested test by which the main purpose rule may be applied does not require actual equivalency, but only bargained-for equivalency. In most of the property cases the lien surrendered was upon property belonging to the new promisor or which he was about to acquire. ${ }^{40}$ There is exact equivalency between the benefit received and the obligation assumed, as is also the case where the consideration moves from the debtor in the form of property purchased, the new promisor promising to pay the debt as part of the purchase price. But in some of the property cases under the main purpose rule the lien surrendered was upon property of the debtor; here the oral promise is only held to be outside the Statute where the pecuniary benefit to the new promisor, so substantial that it can be said that he desired it as his leading object in making the promise, was a result of the surrender of, or forbearance to assert, the lien. What is received by the promisor is only objectively tha' $i$ which is given up to him by the promisee; subjectively, its value may be far greater. For example, $P$ owes a debt of $\$ 125$ to $C$, secured by a chattel mortgage upon $P$ 's teain of mules. $P$ is doing work for $S$, clearing the latter's land, in which use of the team is necessary. In order to prevent

40 Hammond Lumber Co. v. Cravens (1927) 82 Cal. App. 685, 256 Pac. 428; Parker v. Dillingham (1891) 129 Ind. 542, 29 N. E. 23; Luark v. Malone (1870) 34 Ind. 444; Johnson v. Huffaker (1917) 99 Kan. 466, 162 Pac. 1150; Manning v. Anthony (1911) 208 Mass. 399,94 N. E. 466. 
$C^{\prime}$ s foreclosure of his mortgage on the team, $S$ orally promises $C$ to pay $P^{\prime}$ 's debt. Such promise is held outside the Statute. ${ }^{41}$ Although the detriment to $C$ in forebearance from foreclosure is clearly far less in value than the debt, yet the benefit to $S$ from $C$ 's forbearance may well equal the $\$ 125$ obligation assumed, for $S$ wishes his land cleared and without the team $P$ 's services will be of little value. At any rate, $S$ thought so; he bargained for it as the price of the forbearance. In Guth v. First Nat. Bank of Odessa, ${ }^{42}$ a bank holding a mortgage on a farmer's growing crop to secure a $\$ 2,000$ debt, orally promised to pay the farmer's existing supply bill if plaintiff would continue to furnish supplies so that the farmer could harvest his crop. The promise was held original. The benefit to the bank resulted because harvesting the crop became possible; without this the bank's mortgage would be valueless. It was a 'benefit and it was regarded by the bank and bargained for as worth more than the obligation undertaken.

The suggested test of equivalency of benefit to obligation also explains the results in the stockholder cases. An oral promise by a stockholder to pay a debt for which the corporation is liable, in consideration of further advances or credit to the corporation, is held to be within the Statute by the great majority of the decisions, on the stated ground that the benefit to the new promisor is not sufficiently direct and immediate to make it in substance a promise to answer for his own debt. ${ }^{43}$ But fundamentally, the benefit to the promisor is so small in relation to the debt he is answering for, in the great majority of such cases, that the only possible inference is that his purpose is to be a surety for the corporation. Assuming he is the owner of five per cent of the issued stock, ninety-five per cent of the benefit inures to the other stockholders. The situation outlined in the property cases is reversed; detriment to the promisee creditor is large; benefit to the oral promisor is small in relation to the obligation assumed. On the other hand, where the promisor owns all or substantially all of the corporate stock, and he promises directly in form to pay for supplies subsequently sold to the corporation, by the test of equivalency his main purpose is to answer for a debt that is substantially his own; the oral promise should be held outside the Statute. ${ }^{44}$

41 Moore v. McHaney (1915) 191 Mo. App. 686, 178 S. W. 258.

42 (1926) 137 Wash. 280, 242 Pac. 42.

43 The reasoning in Hurst Hardware Co. v. Goodman (1910) 68 W. Va. 462, 69 S. E. 898 , is typical of the stockholder cases.

44 In most sole stockholder cases the promisor is transacting his own business in the corporate naine, so the promise is to pay his own deht. Donovan v. Purtell (1905) 216 
The equivalency test of the main purpose rule also explains the results in the building cases. Where the promise of the owner is to pay the subcontractor for labor and materials thereafter furnished, he is obviously answering for his own debt, receiving exactly what he promised to pay. ${ }^{45}$ On the other hand, where the oral promise is to pay for that which has already been furnished to the general contractor and also what is still to be furnished, unless the promise can be construed as severable, ${ }^{46}$ application of the test produces the result which is actually reached in the cases; the promise is collateral. ${ }^{47}$ Where the beneficial consideration is release of a mechanic's lien perfected against the building, the promise of the owner is original since benefit and obligation are quite clearly the same. ${ }^{48}$ Where the promise is to pay only out of whatever may be due the general contractor from the owner, the promise is clearly to pay the promisor's own debt. He is in no sense a surety, since what he pays he would have no right to recover over from the general contractor.

Finally, what effect will the form in which the promise is made have on the question of applicability of the Statute? It is apparent that the oral promise of one who is a surety may yet be outside the Statute where his leading object in making the promise is to secure to himself such direct pecuniary benefit that it may be said he is primarily answering for his own debt and only incidentally answering for the debt of another. This being so, logically it should make no difference in result what form his promise takes, whether absolute, as "I will pay," or conditioned upon the debtor's default, as "I will pay if $P$ does not." In the clear cases, such as the property cases, where the promisor has received beyond question benefit equal to the obligation undertaken, the difference is either not discussed or if noted is said to be immaterial. ${ }^{49}$ But in a large number of the

III. 629,75 N. E. 334 . But where the separate corporate entity is preserved and the promisc is in form collateral, i.e., to pay if the corporation does not pay, the Statute is usually held to apply even though the promisor owns substantially all of the stock. Bulkley v. Shaw (1942) 289 N. Y. 133, 44 N. E. (2d) 398; Goldie-Klenert Distributing Co. v. Bothwell (1912) 67 Wash. 264, 121 Pac. 60.

45 Cases cited note 26 supra.

46 See note 30 supra.

47 See note 27 supra.

48 See note 33 supra.

${ }^{49}$ Schroyer v. Ruffhead (1927) 122 Kan. 767, 253 Pac. 414; Kahn v. Waldman (1933) 283 Mass. 391,186 N. E. 587 ; Raabe v. Squier (1895) 148 N. Y. 81,42 N. E. 516 ; Green v. Hadfield (18d4) 89 Wis. 138, 61, N. W. 310. 
building ${ }^{50}$ and stockholder cases, ${ }^{51}$ where the new promise is "I guarantee payment" or " $I$ will pay if $P$ defaults," and the undertaking includes existing and future indebtedness, such promises are held within the Statute. ${ }^{.2}$ The reason is not at all obscure. Inclusion of deliveries previously made either results in an obligation greater than the benefit received, or equivalency is doubtful. ${ }^{53}$ In doubtful cases, the fact that the promise is collateral in form is determinative. In other words, oral promises in form to pay the debt of another are presumptively within the Statute. The presumption is rebutted only where it is entirely clear that in substance the promise is to pay the promisor's own debt. ${ }^{54}$

50 Bonner \& Marshall Co. v. Hansell (1914) 189 Ill. App. 474; Gill v. Herrick (1873) 111 Mass. 501 ; Whitschard v. Brody \& Sons (1931) 257 N. Y. 97,177 N. E. 385 ; Higginbotham-Bartlett Co. v. Dickey (Tex. 1930) 27 S. W. (2d) 248.

51 Bulkley v. Shaw, supra note 44; Goldie-Klenert Distributing Co. v. Bothwell, supra note 44.

52 Whitschard v. Brody, supra note 50.

53 Raabe v. Squier, supra note 49.

54 In New York the two latest cases by the Court of Apeals, Whitschard v. Brody, supra note 50, and Bulkley v. Shaw, supra note 44, in terms approved what Professor Williston states to be the "true test" of the Statute, namely, as between new promisor and debtor, which one ought to pay. 2 Wrutston, Contracrs $\S 475$. If tbe debtor ought to pay, the promise is collateral; if the promisor ought to pay, it is original. But tbe Whitschard case was a building case, and the proinise was "I guarantee" payment of both past and future dehiveries. The Bulkley case was a sole stockholder case, and the promise was collateral in form "to put the corporation in funds" to meet deficits. It does not at all follow from these cases that the New York court is committed to a rule by which all oral contracts of suretyship are within the Statute of Frauds irrespective of how much beneficial consideration is received by the new promisor from the creditor. 